\title{
Observations of shoots and roots from interspecific grafted rosaceous shrubs
}

\author{
N. E. KYLE AND T. L. RIGHETTI
}

Authors are research assistant and professar at Oregon State University, Department of Horticulture, Agr. and Life Sciences 4017, Corvallis, Ore. 97331-7304.

\begin{abstract}
Plants with various shoot and root combinations of Cowania mexicana var. stansburiana (Torr.) Jeps. (cliffrose), Purshia glandulosa Curran (desert bitterbrush), and Purshia tridentata (Pursh) DC. (antelope bitterbrush) were relatively easy to produce by grafting. The foreign roots or shoots in multi-shoot or multi-root systems were not as vigorous as the original scion or rootstock. With time the original scion or rootstock became dominant and the foreign portions usually senesced. If growth of the original scion or rootstock was restricted by pruning or removal, satisfactory growth for both shoot or root types occurred. Manipulating grafted systems where Fallugia paradoxa, (D. Don) Endl., Apache plume, (a non-nodulating genus) is combined with any of the above 3 nodulating species was much more difficult. Graft incompatibility occurred in most intergeneric Fallugia systems, but some combinations survived for several years. A large quantity of nodules was produced on 1 very sparsely rooted $P$. tridentata scion attached to a Fallugia rootstock. Apparently, the plant derived much of its nitrogen from Purshia nodules, and the majority of its other nutrients and water from the Fallugia roots.
\end{abstract}

Key Words: nitrogen fixation, micrografting, Cowania mexicana, Fallugia paradoxa, Purshia glandulosa, Purshia tridentata.

Cowania mexicana var. stansburiana (Torr.) Jeps, Fallugia paradoxa (D. Don) Endl., Purshia glandulosa Curran and $P$. tridentata (Pursh) DC. are important browse shrubs (Stubbendieck et al. 1992). Purshia and Cowania are useful for revegetating disturbed areas (McArthur et al. 1974). A nitrogen fixing symbiosis with the Actinomycete, Frankia (Webster et al. 1967, Bond 1976, Righetti and Munns 1980) promotes plant growth in nitrogen poor soils (Guinta et al. 1978).

Purshia glandulosa, $P$. tridentata and $C$. mexicana exhibit variability in growth, habit, incidence of nodulation and palatability (Nord 1965, Stutz 1972, Nelson 1983, Righetti et al. 1983). Natural hybridization between Cowania and Purshia is common (Stutz and Thomas 1964) and artificial crosses have been successful (Blauer et al. 1975). Rich variability and genetic compatibility suggests plant improvement (Stutz 1972, Monsen and Davis 1985) could be fruitful. Grafting to produce various root-

Research was funded in part by National Science Foundation Grant PCM8204885 .

Agr. Exp Sta. tech paper 9750.

Manuscript accepted 12 Aug. 1995. stock-scion combinations may help determine whether variable characteristics are due to root or whole plant effects (Westwood 1978, Roberts and Westwood 1976). In vitro grafting has produced various rootstock scion combinations of Purshia, Cowania, and Fallugia (Kyle et al. 1986, Kyle and Righetti 1988).

Roots and shoots interact in regard to nodulation and nitrogen fixation (Dawson and Gordon 1979, Lawn et al. 1974, Delves et al. 1986, Miller et al. 1987). It may be possible to better understand the nitrogen fixing process in rosaceous shrubs by utilizing grafted systems. The goal of this research was to establish the feasibility of producing grafted systems with more than one species of shoots and roots.

\section{Material and Methods}

Shoots were proliferated on a media previously described (Kyle and Righetti 1988) except that benzyladenine was reduced to 1 mg liter ${ }^{-1}$ and tissue culture agar was reduced to $7 \mathrm{~g} 1$ iter $^{-1}$. The rootstocks were prepared from aseptically germinated seedlings. Dormancy in Cowania and Purshia seeds required pretreatment to allow consistent germination. Pretreatment consisted of soaking seeds overnight in constantly stirred distilled water. Nicking seed coats prior to surface sterilization also assisted in overcoming dormancy. Dormancy did not occur in Fallugia. All seeds were surface sterilized then placed on germination medium as previously described (Kyle et al. 1986) except that $258 \mathrm{mg}^{1} \mathrm{iter}^{-1}$ $\mathrm{CaSO}_{4}-2 \mathrm{H}_{2} \mathrm{O}$ was used as a calcium source.

Grafting was performed under aseptic conditions using a dissecting microscope. A seedling 50-100 mm long was decapitated leaving ca. $1 \mathrm{~cm}$ of hypocotyl above the root. A 2-3-mm-deep cleft was cut in the hypocotyl. The scion consisted of tissue isolated from shoots proliferated in vitro. Since we were not concerned with virus transmission, a large scion consisting of the apical 1-5 $\mathrm{mm}$ was used to increase the survival rate. The scion was inserted into the cleft in the hypocotyl, and the plant was then inserted into a modified Heller (1949) support in a $25 \times 150$ $\mathrm{mm}$ test tube that allowed the roots to be viewed.

Grafted plants were transferred to soil as previously described (Kyle and Righetti 1988). The total number of grafted systems and percent survival 1-year after grafting are.presented elsewhere (Kyle and Righetti 1988). Grafts were continually produced over a 2-year period. In addition to the grafted systems previously described (Kyle and Righetti 1988), 17 additional $P$. tridentata scions on $F$. paradoxa rootstocks were produced for this study. 
Grafted systems surviving more than 1 year were transplanted into $1 \mathrm{~kg}$ of a $1: 1$ soil:vermiculite mix in the greenhouse. Similar size seedlings of all 4 species were transplanted into the mix at the same time to serve as controls. Since pure cultures of Frankia that produce nodules on rosaceous shrubs are not available, soil in the soil:vermiculite mix was from several locations known to produce nodulated seedlings. After at least 18 months of growth in the soil:vermiculite mix, treatments to produce grafted systems with shoots or roots of more than 1 species began.

Scions were brought into contact with soil to induce rooting. Either the shoot was bent down to contact the soil, or soil was held around the shoot in a small plastic container. An example is the $P$. tridentata scion, $F$. paradoxa rootstock system shown in Fig. 5. After pruning to remove $2 / 3$ of its growth, a container $(200 \mathrm{ml})$ of soil known to produce nodules on other systems was fixed around 1 branch of the $P$. tridentata scion. Rootstocks of grafted plants were forced to sprout through vigorous pruning of their scions.

After 9 months of growth in the soil:vermiculite mix, no nodules were produced on any Fallugia roots, while all grafted systems with Purshia and Cowania rootstocks and all Purshia and Cowania seedlings were well nodulated. Thereafter regular additions of $\mathrm{N}$, in the form of 3 mmoles $\mathrm{NH}_{4} \mathrm{NO}_{3}$ /pot every 6 months, were made to supply enough $\mathrm{N}$ to maintain plant systems with Fallugia rootstock. Fallugia seedlings growing in the mix were treated similarly. During the last year of observation, Fallugiarooted systems and Fallugia seedlings received no fertilizer. Grafted systems with Purshia and Cowania rootstocks and all Purshia and Cowania seedlings were grown in the soil mix without $\mathrm{N}$ additions.

Plants were harvested between 6 months and 1 year after the root- or shoot-inducing treatments were initiated. Plants were dissected, and the dry weights of nodules, roots, and shoots of each species were measured. When soil in a small container surrounding the scion of nodulating species produced nodules on an otherwise non-nodulated system, more extensive dissection was initiated. Leaf and twig samples from branches originating above and below the nodulated portion of the scion were collected.

All plant tissues were dried in a tunnel dryer for 48 hours at

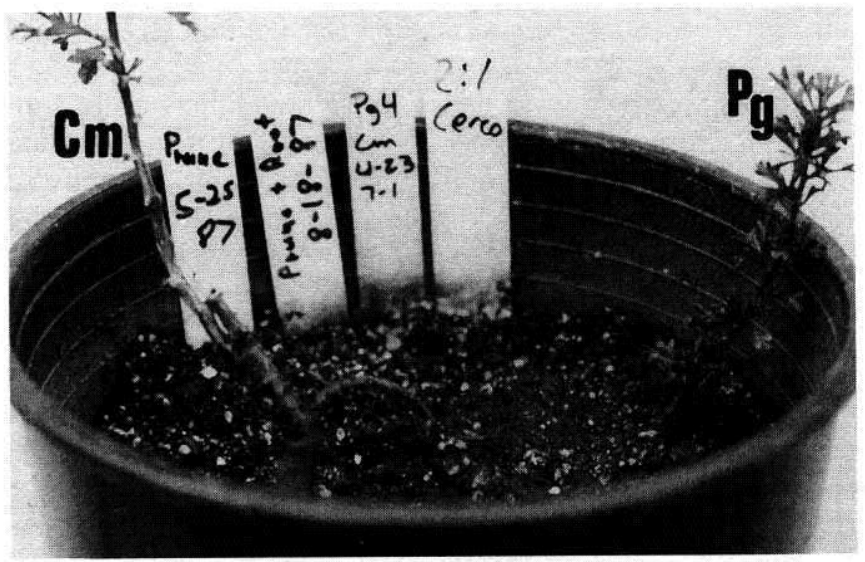

Fig. 1. Purshia glandulosa scion on Cowania mexicana rootstock with a $C$. mexicana sprout. The $P$. glandulosa scion has been bent and is in contact with the soil.

Abbreviations: $\mathrm{Cm}=$ Cowania mexicana, $\mathrm{Pg}=$ Purshia glandulosa $70^{\circ} \mathrm{C}$. Subsamples of dried tissues were ground in a roller grinder (Smith and Myung 1990) prior to determining N concentration using a Europa Scientific Stable Isotope Analyser. Similar evaluations were made on ungrafted seedlings of the same age.

\section{Results and Discussion}

It is possible to produce plants with roots of 2 different species and shoots of 2 different species. Some examples are discussed below. Approximately $7 \%$ of grafted systems with Purshia or Cowania rootstock produced rootstock sprouts when the scion was vigorously pruned. When a scion of any of the 4 species was surrounded with soil, rooting occurred within 3 months in $75 \%$ of the rooting attempts. In Fig. 1 and 2 a plant with a $P$. glandulosa scion and $C$. mexicana roots sprouted from the rootstock, forming a plant with both Cowania and Purshia shoots on a Cowania root. Shoots were pruned to maintain similar biomasses of the 2 species. The Purshia scion was then rooted, producing a plant with foreign roots and shoots introduced on another genus (Fig. 1 and 2).

In Fig. 3, a $P$. tridentata scion on a $P$. glandulosa rootstock rooted to produce a plant with roots of 2 species. Both roots nodulated, demonstrating that it is possible for foreign roots and nodules to be associated with a different species. In experimental systems involving multiple scions or rootstocks, shoot and root pruning can be used to produce plants with whichever dominant scion or rootstock is desired.

It is relatively easy to produce systems with shoots and roots of more than 1 species for various $C$. mexicana, $P$. glandulosa, and $P$. tridentata combinations. Since all 3 of these closely related species nodulate, it is not surprising that foreign nodules can occur. Cowania mexicana has been treated as a species of

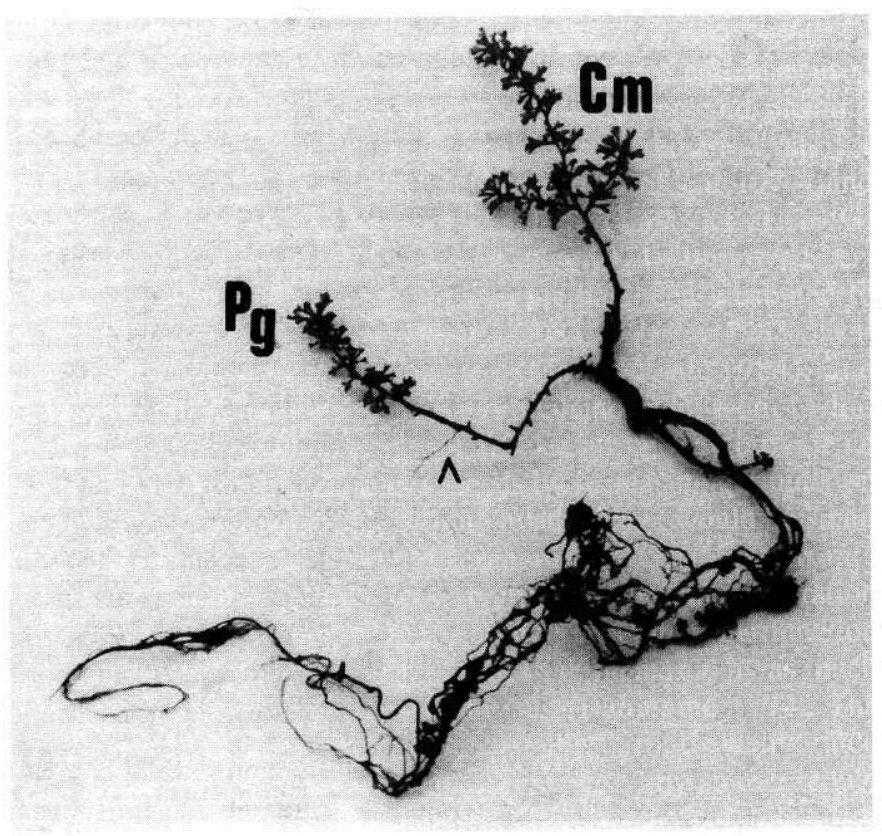

Fig. 2. The same plant as in Fig. 1, showing roots and shoots of both species. The small Purshia glandulosa roots are marked with an arrow.

Abbreviations: $\mathrm{Cm}=$ Cowania mexicana, $\mathrm{Pg}=$ Purshia glandulosa 


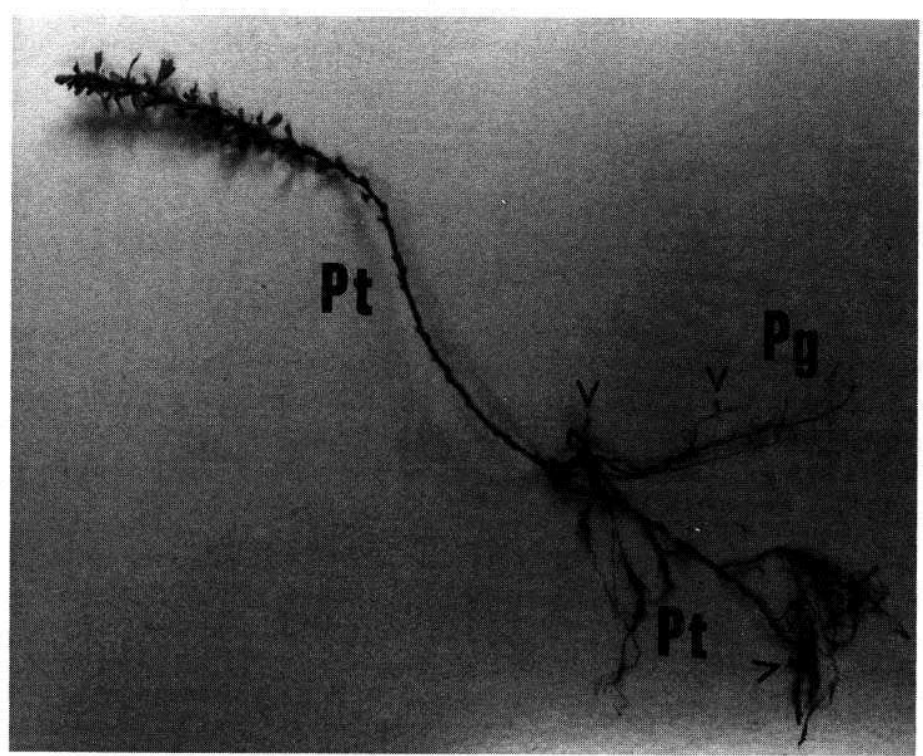

Fig. 3. Purshia tridentata scion on $\boldsymbol{P}$. glandulosa rootstock. Scion has rooted. Arrows indicate nodules.

Abbreviations: $\mathbf{P g}=$ Purshia glandulos, $\mathbf{P t}=$ Purshia tridentata

Purshia (i.e., P. mexicana) (Welsh et al. 1987), thus it is obviously closely related to the other Purshia species. In previous studies Kyle and Righetti (1988), found nodules present on the rootstock from a different species than the scion reduced acetylene at a rate comparable to nodulated non-grafted seedlings.

The foreign roots or shoots in these multi-shoot or multi-root systems are never as vigorous as the original scion or rootstock. In long-term experiments ( 6 months- 1 year), foreign material usually senesces as growth is dominated by the original rootstock or scion. However, if growth of the original scion or rootstock is restricted by pruning, approximately equal growth for both shoot types or root types can be maintained. It is not clear if a foreign nodulated root will continue to receive plant resources if the rest of the grafted system is uninoculated, nitrogen deficient, and without nodules.

Manipulating grafted systems where $F$. paradoxa is combined with any of the other 3 species is much more difficult. A total of 761 grafts of all possible graft combinations of $F$. Paradoxa, $C$. mexicana, $P$. glandulosa, and $P$. tridentata were performed. To date, $P$. tridentata scions on $F$. paradoxa rootstocks were the only combination to survive for over 18 months. Most Fallugia systems fail after plants become dormant during their first winter season and do not resume new growth in spring. It may be possible to overcome this seasonal quiescence using growth chambers. Recent experience suggests that Fallugia heterografts become quiescent prematurely, especially when Fallugia scions are nitrogen-deficient. It may be important to control photoperiods and supply combined nitrogen to produce more vigorous plants prior to transplanting into the nitrogen-deficient soils used to determine nodulation capability. It would be interesting to determine graft compatibility of Purshia with other Cowania species which are likely to be more closely related than F. Paradoxa but not as similar as $C$. mexicana.

Only 4\% (7 of 162) of $P$. tridentata scions on Fallugia rootstocks survived 12 months, but several of those grew in the greenhouse for over 4 years in the soil mix that produced nodules on other plants. Plants with Fallugia rootstock did not nodulate.

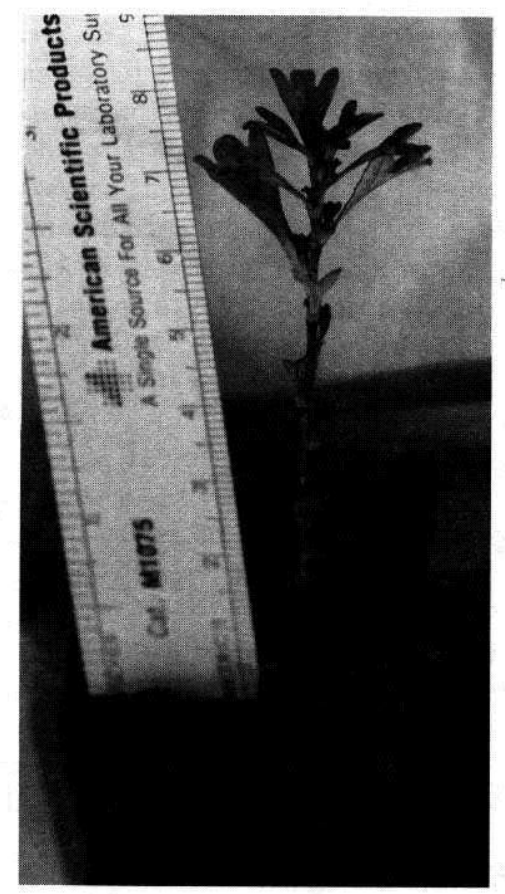

Fig. 4. Purshia tridentata scion on $\boldsymbol{F}$. paradoxa rootstock. Lower leaves have abscised and new growth has been initiated.

Each fall, these plants dropped their leaves, and resumed growth in the spring (Fig. 4). The plant shown in Figure 4 reached $1 \mathrm{~m}$ in shoot height by the end of its third season (Fig. 5). After root inducing treatments were applied, the scion rooted and subsequently nodulated (Fig. 6) during the following growing season. The shoot above the nodulated roots grew more vigorously than the shoot below these roots. All tissues above the nodulat-

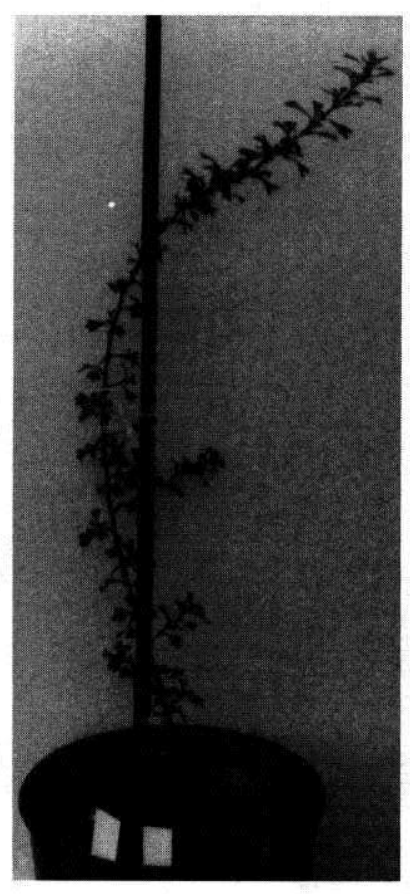

Fig. 5. The same plant as in Fig. 4 after its third season. 


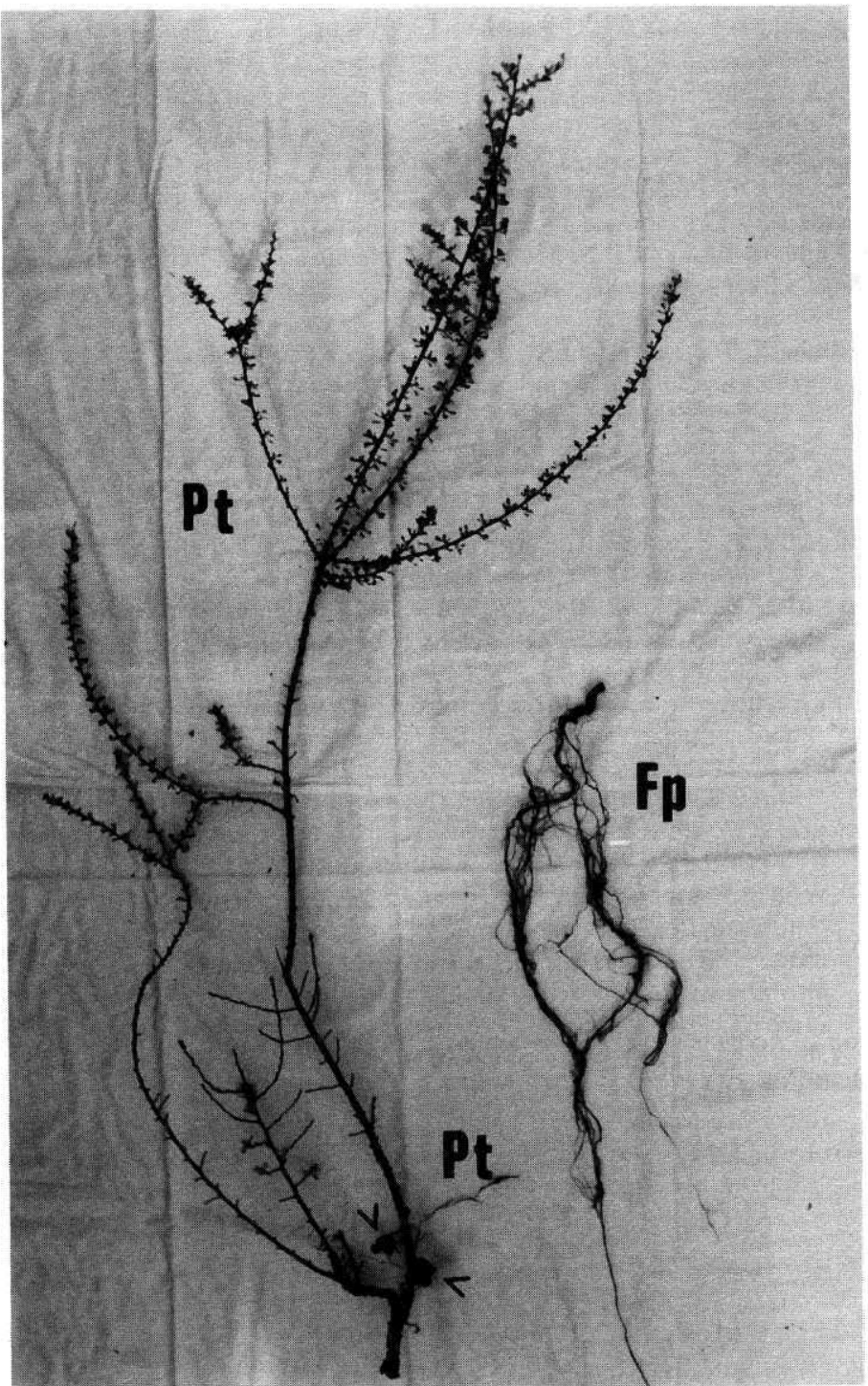

Fig. 6. The same plant as in Fig. 4 after its fourth season showing roots and nodules on a rooted portion of the Purshia scion. Arrows indicate nodules.

Abbreviations: $\mathbf{P t}=$ Purshia tridentata, $\mathbf{F p}=$ Fallugia paradoxa

ed roots were higher in percent $\mathrm{N}$ than corresponding tissues on branches that originated below the nodules (Table 1). All tissues of the grafted plant also had higher $\mathrm{N}$ concentrations than those of an ungrafted Fallugia plant of similar age growing in the same soil mix. It appears that $\mathrm{N}$ fixed by Purshia nodules was transported to other tissues of the grafted plant, including its Fallugia roots.

An ungrafted, but well nodulated, $P$. tridentata seedling of approximately the same size and age of the grafted $P$. tridentata $\mathrm{x}$ Fallugia system, and growing in the same soil mix, contained $\mathrm{N}$ concentrations only slightly higher than the grafted system (Table 1). In the process of exposing $P$. tridentata nodules to gaseous ${ }^{15} \mathrm{~N}$, the grafted system was broken at the graft union. Therefore, we cannot unequivocally demonstrate transfer of biologically fixed $\mathrm{N}$ to Fallugia roots. However, we consider this is likely based on N concentration data. Purshia roots on the grafted system were densely nodulated. Nodules formed a higher percentage
Table 1. Nitrogen concentrations of various tissues from a grafted system where a Purshia tridentata scion was grafted to a Fallugia paradoxa rootstock. Samples were collected 7 months after the scion produced roots and root nodules.

\begin{tabular}{llc}
\hline \hline Plant & Tissue & Nitrogen \\
\hline Grafted Plant & Fallugia roots & $(\%)$ \\
& Purshia roots & 1.20 \\
& most active nodules & 1.57 \\
& remaining nodules & 1.63 \\
& leaves above Purshia roots & 0.94 \\
& $\begin{array}{l}\text { leaves from branches originating } \\
\text { below } \text { Purshia roots }\end{array}$ & 2.03 \\
& stems above Purshia roots & 1.48 \\
& stems from branches \\
& originating below Purshia roots & 0.80 \\
Fallugia seedling & roots & 0.72 \\
& leaves & 0.59 \\
& leaves & 0.82 \\
& & 2.66 \\
\hline
\end{tabular}

of total root biomass in the grafted system $(>20 \%)$ than amounts reported in other studies for $P$. tridentata seedlings (Bond 1976, Righetti et al. 1983).

Nodulated roots in this small container were not sufficient to maintain a plant of this size. Purshia roots (excluding nodules) amounted to approximately $11 \%$ of the total root biomass of the Fallugia $\times$ Purshia system. Apparently, the plant was deriving much of its nitrogen from Purshia nodules while deriving the majority of its other nutrients and water from Fallugia roots. It appears possible for a small portion of nodulated roots to supplement $\mathrm{N}$ needs of a plant while the majority of a root system is incapable of fixing $\mathrm{N}$.

We realize the low survivability of Fallugia $\times$ Purshia heterografts limits their utility in scientific studies. Low survivability and losses that occur with additional manipulations severely limit the amount of material available. Our observations required years of effort and, in the end, are mostly based on a single surviving system. However, the limited success suggests that a functioning foreign nodule is possible. The partial graft compatibility previously reported (Kyle et al. 1986, Kyle and Righetti 1988) and demonstrated here has clearly occurred. If the Fallugia rootstock in plants similar to the system in Figure 5 could be induced to sprout, a workable model system, with foreign nodules supplying $\mathrm{N}$ to non-fixing shoots and roots, would result.

A wide variety of different scion $\mathrm{x}$ rootstock combinations with $C$. mexicana, $P$. glandulosa, and $P$. tridentata are easily produced. Although it is unlikely that grafted systems will ever be used in rangeland revegetation, there may be special situations where grafted ornamental or research systems are appropriate. These multi-shoot and multi-root plants could be used to assess root effects vs. whole plant effects in differences in growth, habit, palatability or nodulation. They could also be used to determine whether it is possible for a foreign nodule to function, and the consequences to the plant with regard to nitrogen carriers, carbohydrate partitioning, and nitrogen-fixing efficiency. 


\section{Literature Cited}

Blauer, A.C., A.P. Plummer, E. D. McArthur, R. Stevens, and B. C. Guinta. 1975. Characteristics and hybridization of important intermountain shrubs. I. Rose family. USDA Forest Serv. Res. Paper INT169. Ogden, Utah.

Bond G. 1976. Observations on the root nodules of Purshia tridentata. Proc. Roy. Soc. London Ser. B 193:127-135.

Dawson, J.O., and J.C. Gordon. 1979. Photoassimilate supply and nitrogen fixation in Alnus, p. 187-195. In: J.C. Gordon, C.T. Wheeler, and D.A. Perry (eds.). Symbiotic nitrogen fixation in the management of temperate forests. Oregon State Univ. Forest Res. Lab., Corvallis, Ore.

Delves, A.C., A. Matthews, D.A. Day, A.S. Carter, B.J. Carroll, and P.M. Gresshoff. 1986. Regulation of the soybean-Rhizobium nodule symbiosis by root and shoot factors. Plant Physiol. 82:588-590.

Guinta, B.C., R. Stevens, K.P. Jorgensen, and A.P. Plummer. 1978. Antelope bitterbrush. Utah St. Div. of Wildlife Resources Pub. No. 7812. Salt Lake City, Utah.

Heller, R. 1949. Sur l'emploi de papier filtre sans cendres comme support pour les cultures de tissus végétaux C. R. Soc. Biol. 143:335-337.

Kyle, N.E. and T.L. Righetti. 1988. Survival of intergeneric micrografted Rosaceae. Bot. Gaz. 149:21-24.

Kyle, N.E., J.L. Jakobek, R.A. Backhaus, J.C. Stutz, and T.L. Righetti. 1986. Micrografting between $\mathrm{N}$-fixing and non-N-fixing genera of the Rosaceae. Bot. Gaz. 147:243-246.

Lawn, R.J., K.S. Fischer, and W.A. Bunn. 1974. Symbiotic nitrogen fixation in soybeans. II. Interrelationships between carbon and nitrogen assimilation. Crop Sci. 14:17-22.

McArthur, E.D., B.C. Guinta, and A.P. Plummer. 1974. Shrubs for restoration of depleted ranges and disturbed areas. Utah Sci. 35:28-33.

Miller, J.D., L.M. Scott, and G.C.J. Fernandez. 1987. Influence of root and shoot on N2 fixation in cowpea. HortScience 22:1313-1315.

Monsen, S.P. and J.N. Davis. 1985. Progress in the improvement of selected western North America rosaceous shrubs, p. 93-100. In: J.R. Carlson and E.D. McArthur (eds.). Proc. range plant improvement in western North America symp. Salt Lake City. Society for Range Manage. Denver, Colo.
Nelson, D.L. 1983. Occurrence and nature of actinorhizae on Cowania mexicana and other Rosaceae, p. 225-234. In: A.R. Tiedemann and R.L. Johnson (eds.). Proc. research and management of bitterbrush and cliffrose in western North America Symp. USDA Forest Serv. Gen. Tech. Rep. INT-152. Ogden, Utah.

Nord, E.C. 1965. Autecology of bitterbrush in California. Ecol. Monogr. 35:307-334.

Righetti, T.L. and D.N. Munns. 1980. Nodulation and nitrogen fixation in cliffrose Cowania mexicana var. Stansburiana (Torr. Jeps.). Plant Physiol. 65:411-412.

Righetti, T.L., C.H. Chard, and D.N. Munns. 1983. Opportunities and approaches for enhancing nitrogen fixation in Purshia, Cowania, and Fallugia, p.214-224. In: A.R. Tiedemann and K.L. Johnson (eds.). Proc. research and management of bitterbrush and cliffrose in western North America symp. USDA Forest Serv. Gen. Tech. Rep. INT-152. Ogden, Utah.

Roberts, A.N. and M.N. Westwood. 1976. Rootstock studics with peach and Prunus subcordata Benth. Fruit Var. J. 35:12-20.

Smith, J.L. and H.U. Myung, 1990. Rapid procedures for preparing soil and KCI extracts for ${ }^{15} \mathrm{~N}$ analysis. Commun. in soil Sci. and Plant Anal. 21:2173-2179.

Stubbendieck, J., S.L. Hatch, and C.H. Butterfield. 1992. North American Range Plants. $4^{\text {th }}$ ed. Univ. of Nebraska Press, Lincoln, Neb.

Stutz, H.C. and L.K. Thomas. 1964. Hybridization and introgression in Cowania and Purshia. Evolution 18:183-1995.

Stutz, H.C. 1972. Genetic improvement in crop species as contrasted with possibilities in shrubs, p. 139-143. In: C.M. McKell et al. (eds.) Wildland shrubs-their biology and utilization. USDA Forest Serv. Gen. Tech. Rep. INT-1. Ogden, Utah.

Webster, S.R., C.T. Youngberg, and A.G. Wollum. 1967. Fixation of nitrogen by bitterbrush [Purshia tridentata (Pursh) DC]. Nature 216:392-393.

Welsh, S.L., N.D. Atwood, S. Goodrich, and L.C. Higgins. 1987. Utah Flora. Great Basin Naturalist Memoirs, No. 9. Brigham Young University, Provo, Utah.

Westwood, M.N. 1978. Temperate zone pomology. W.H. Freeman and Company, San Francisco, Cal. 